Int. Archs Allergy appl. Immun. 1982;67:I-IV

\title{
Contents, Vol. 67, 1982
}

\section{No. 1}

Original Paper

Demonstration of Accelerated and Increased Migration Inhibition Factor Release in vivo in a PPD Retest Reaction Maarsseveen, A.CM. van; Bomhof, G.; Scheper, R.J. . 1

Mothers of Infants with Neonatal Group B Streptococcal Sep-ticemia Are Poor Responders to Bacterial Carbohydrate Antigens

Christensen, K.K.; Christensen, P.; Lindberg, A.; Linden, V 7

Histamine Release from Washed Whole Blood. A Method Suit able for Routine Diagnosis of Type I Allergy

Diamant, B.; Patkar, S 13

Subpopulations of Pig Blood E-Rosette-Forming Lymphocytes and Thymus-Dependent Null Cells: Separation by Nylon Wool Columns, Rosette Formation and MacrophageDependent Mitogen and Antigen Responsiveness Outteridge, P.M.; Binns, R.M.; Licence, S.T 18 Mitotic Response of Rabbit Peripheral Blood Lymphocytes to a Factor in Normal Rabbit Serum: A Possible Genetic Poly morphism Yonish-Rouach, E.; Dubiski, S.; Cinader, B 25

Studies on the Binding of Immunoglobulins and Immune Com plexes to the Surface of Human Platelets: IgG Molecules React with Platelet Fc Receptors with the CH3 Domain Endresen, G.K.M.; Førre, 033

Inhibition of Protein A-Induced Lymphocyte Colony-Forming Cells by Con A-Generated Suppressor Cells or Their Culture Fluid Nemoto, H.; Shibasaki, M.; Suzuki, S.; Kuroume, T. . . . 40

Evidence that Tissue Mast Cells Derive from Mononuclear Phagocytes Czarnetzki, B.M.; Sterry, W.; Bazin, H.; Kalveram, K.J. . 44

Comparative Studies on Tree Pollen Allergens. II. Isolation of Alder (Alnus incana) Pollen Allergens: Purification and Some Characteristics of the Major Allergen pi 4.78

Florvaag, E.; Elsayed, S.; Apold, J 49

Effect of Irradiation on Concanavalin A-Induced Suppression of Mitogen Responses in Human Lymphocyte Cultures Petrini, B.; Wasserman, J.; Blomgren, H.; Glas, U.; Baral, E.; Strender, L.-E 57 Increased Levels of IgG4 Subclass in 5 Patients with Acquired Respiratory Disease Nieuwkoop, J.A. van; Brand, A.; Radl, J.; Skvaril, F. . . 61 
Induction of Cytotoxic Lymphocytes by Protein Derived from Staphylococcus aureus. I. Protein-A-Induced, Protein-A-

Dependent Cytotoxicity of T Lymphocytes against Human

Lymphoblastoid Cell Lines

Sumiya, M.; Kano, S.; Takaku, F 66

Plasma Fibrinogen Concentration in ABO-Hemolytic Disease

of the Newborn

Romano, E.L.; Linares, J.; Suárez, G 74

Preferential Induction of Cell-Mediated Immunity by Chemi

cally Modified Carcinoembryonic Antigen

Staab, H.-J.; Anderer, F.A 78

Idiotypic and Structural Analysis of Monoclonal Human Im

munoglobulins with Anti-Streptolysin O Activity

Riesen, W.F.; Braun, D.G.; Skvaril, F.; Mansa, B 86

Inhibitory Effect of Transplanted Syngeneic Thymus Frag

ments, Thymus Epithelium and Thymocytes on the In

creased Contact Sensitivity Reaction in the Adult Thymec-

tomized Mouse

Olafsson, J.H.; Lindholm, L.; Roupe, G 93

Short Communication

Boosterable IgE Antibody Response in Mice without the Use of

Adjuvant

Hall, E.; Ahlstedt, S.; Kristofferson, A 96

Book Reviews 99

Erratum $\quad 100$

No. 2

Original Paper

BL-5255. I. Activity in Animal Models of Immediate Hyper-

sensitivity Reactions

Siminoff, P.; Reed, III, F.C.; Schurig, J.E 101

Suppression of IgE Antibody Production in Sensitized Mice

and Rats by Tolerogenic Conjugates of Synthetic Hydro-

philic Polymers with Antigen or Hapten: Effect on Antigen-

Induced Histamine Release from Peritoneal Mast Cells

Holford-Strevens, V.; Lee, W.Y.; Kelly, K.A.; Sehon,

A.H 109

IgG4 and Release of Histamine from Human Peripheral Blood

Leukocytes

Toorenenbergen, A.W. van; Aalberse, R.C 117

Serologically Defined Antigens on the Surface of Somatic Hy

brid Cells

Rubio, N 123

Studies on the Cellular Site of Action of the Adjuvant Activity of Saponin for Sheep Erythrocytes

Bomford, R 127 
Clinical Studies of a Purified Timothy Pollen Extract: De-sensitization Therapy with a Purified Timothy Pollen Preparation Compared to a Crude Timothy Pollen Extract. II. Results of the Tests in vitro and Their Relation to Symptoms and Tests in vivo Nordvall, S.L.; Berg, T.; Johansson, S.G.O.; Lanner, Å. .132

Delayed-Type Hypersensitivity in Rabbits. Comparison of the Adjuvants Dimethyl Dioctadecyl Ammonium Bromide and Freund's Complete Adjuvant

Snippe, H.; Reuver, M.J. de; Beunder, J.W.; Meer, J.B. van

der; Wichen, D.F. van; Willers, J.M.N 139

Contents

III

Immunogenetic Studies in Essential Hypertension among Black Patients. I. Correlative Studies of Serum Autoantibody For mation

Patel, R.; Johnson, J.; Ansari, A 145

Enhanced Cellular Immune Response to Type I Collagen in Patients with Periodontal Disease

Mammo, W.; Singh, G.; Dolby, A.E 149

Tolerance Induction via Antigen Inhalation: Isotype Specifici ty, Stability, and Involvement of Suppressor T Cells

Holt, P.G.; Leivers, S 155

Increase in Rosette-Forming T Cells with Autologous Human Erythrocytes in Lymphocytes of Patients with Tuberculosis by in vitro Stimulation with Purified Protein Derivative Tsuyuguchi, I.; Shiratsuchi, H.; Fujiwara, H 161 Regulation of Natural Killer Activity in vivo. III. Effect of Hypophysectomy and Growth Hormone Treatment on the Natural Killer Activity of the Mouse Spleen Cell Popula tion

Saxena, Q.B.; Saxena, R.K.; Adler, W.H 169

Development of Beryllium Lymphocyte Transformation Tests in Chronic Beryllium Disease

Williams, W.R.; Williams, W.J 175

Short Communications

Is Eosinophil Chemotactic Factor Identical with Leukotriene

$\mathrm{B}$ ?

Czarnetzki, B.M 181

Effects of Levamisole and D-Penicillamine on Contact Sensi tivity to Oxazolone in Rats

West, G.B 184

Potentiated Reagin Response to Ovalbumin in Schistosoma mansoni Infected Rats and in Rats Treated with a Soluble Metabolic Product from Adult Worms

Rousseaux-Prévost, R.; Dessaint, J.-P.; Capron, A 187 
IgE and Haemagglutinating Antibody Production in Mice fol lowing Intranasal Immunization with Ryegrass Pollen

McCaskill, A.C.; Hosking, C.S.; Hill, D.J 191

Letter to the Editor 194

Book Reviews 195

No. 3

Phagocytosis of Mast Cell Cranules by Mononuclear Phago

cytes, Neutrophils and Eosinophils during Anaphylaxis

Baggiolini, M.; Horisberger, U.; Martin, U 219

C3a-Induced Lysosomal Enzyme Secretion from Human Neu

trophils. Lack of Inhibition by f met-leu-phe Antagonists

and Inhibition by Arachidonic Acid Antagonists

Showell, H.J.; Glovsky, M.M.; Ward, P.A 227

Effect of Fixation on the Light Microscopical Visualization of Mast Cells in the Mucosa and

Connective Tissue of the Human Duodenum

Ruitenberg, E.J.; Gustowska, L.; Elgersma, A.; Ruitenberg,

H.M 233

Quantitation of Antibody Production in Mouse Bone Marrow

during the Secondary Response to Sheep Erythrocytes

Koch, G.; Weerheijm-De Wit, C; Benner, R 239

Dissociation of Immune Complexes in Tissue Sections by Excess of Antigen

Penner, E.; Albini, B.; Glurich, I.; Andres, G.A.; Milgrom,

F 245

Immune Responses in Nonhaired Mice

Smith, S.M.; Forbes, P.D.; Linna, T.J254

Antibody Responses to Impurities of Penicillin in Infants and

Rabbits

Ahlstedt, S.; Jodal, U.; Mårild, S.; Sjövall, J 262

Detection of Antibodies to Streptococcal Mucopeptide in Pa

tients with Rheumatic Disorders and Normal Controls

Pope, R.M.; Rutstein, J.E.; Straus, D.C 267

Short Communications

Effect of EDTA on the Solid Phase Clq Immune Complex

Assay

Davey, M.P.; Korngold, L 275

Association of Anti-F ( $a b^{5} / 8$ Antibodies (Pepsin Agglutinators)

with Immune Complexes as Determined by Enzyme-

Linked Immunosorbent Assays

Davey, M.P.; Korngold, L 278

Selective Inhibition by Betamethasone of Allergen-Induced Re

lease of SRS-A from Human Lung

Hammond, C.V.; Hammond, M.D.; Taylor, W.A 284

Immunopotentiation of the IgE Antibody Response by 13-cis-

Retinoic Acid

Barnett, J.B 287

Book Reviews 290 
Original Paper

Influence of Palmitic Acid on Mouse Lymphocyte Function in

vivo and in vitro

Tizard, I.; Sheppard, J 197

Antibody-Dependent, Cell-Mediated Cytotoxicity of Nucleated

Mammalian Cells by Rat Eosinophils and Neutrophils

Lopez, A.F.; Sanderson, C.J 200

Anaphylactic and Precipitating Antibody Responses of Aging

A/J Female Mice

Crowle, A.J.; Grove, N.J.; Miller, J.L206

Relationship between Tissue Sensitization and IgE Antibody

Production in Rats Infected with the Nematode, Nippos-

trongyíus brasiliensis

Befus, A.D.; Johnston, N.; Berman, L.; Bienenstock, J. . . 213

No. 4

Original Paper

Isolation and Partial Characterisation of Three Major Allergens

in an Extract from Cow Hair and Dander

Prahl, P.; Bucher, D.; Plesner, T.; Weeke, B.; Løv/enstein,

H 293

The Use of Host Strain Variation to Assess the Significance of Mucosal Mast Cells in the Spontaneous Cure Response of

Mice to the Nematode Trichuris Muris

Lee, T.D.G.; Wakelin, D 302

IV

Contents

Carrier and Hapten Functions in Immune Deviation. III. Pos sible Antigenic Competition between Hapten and Carrier

Determinants at the Macrophage Level

Neveu, P.J 306

Immune Response to Trichomonas vaginalis. I. Genetic Regu

lation of IgE Antibody Response to T. vaginalis in Mice

Yano, A.; Kaji, R.; Kojima, S.; Ovary, Z 310

Enhancement of Suppressor Cell Generation in Human Mixed

Lymphocyte Cultures by Interferon

Onsrud, M 315

In vitro Augmentation of Human Natural Killer (NK) Cell

Activity by a Streptococcal Preparation OK-432 and Its

Extracts, Protein $\mathrm{M}$ and Polysaccharides

Wakasugi, H.; Oshimi, K.; Kasahara, T.; Miyata, M.; Mo-

rioka, Y 322

Immune Response of Dogs and Rabbits to Intrabronchial Tri-mellitic Anhydride Sale, S.R.; Patterson, R.; Zeiss, C.R.; Fiore, M.; Harris,

K.E.; Yawn, D329 
Contact-Dependent Expression of Actin in Chicken Lympho

cytes in vitro

Woods, G.M.; Boyd, R.L 335

The Anti-Allergic Activity of Benoxaprofen [2-(4-Chlorophe-nyl)- $\alpha$-Methyl-5-Benzoxazole Acetic Acid] - A Lipoxygen-ase Inhibitor

Boot, J.R.; Sweatman, W.J.F.; Cox, B.A.; Stone, K.; Daw-

son, W 340

In vivo Modulation of Human Lymphocyte Fc $\gamma$-Receptors in

Response to Oral Antigen (Cows' Milk) Challenge

Sandilands, G.P.; Reid, F.M.; Galbraith, I.; Peel, M.G.;

Lewis, C.J 344

Discrepancy Between Biological Activity of Thymosin and Its

Cyclic Nucleotide-Modulating Activity

Morikawa, A.; Suzuki, S.; Kuroume, T

351

The Effect of a Low Protein Diet on the Immunogenic Activity

of Murine Peritoneal Macrophages

Rose, A.H.; Holt, P.G.; Turner, K.J 356

Pharmacology of a New Orally Active Antiallergic: Pyrido [1,2-

a] Pyrimidine, ucb L 140 (CHINOIN 1045) in Rats

De Vos, C; Dessy, F.; Hermecz, I.; Meszaros, Z.; Breining, $\mathrm{T} \quad 362$

Isolation and Some Properties of an IgG Fc-Binding Protein from Group A Streptococci Type 15

Grubb, A.; Grubb, R.; Christensen, P.; Schalén, C 369

Short Communications

Antibodies to Type II Collagen Measured by Mixed Reverse

(Solid-Phase) Passive Antiglobulin Haemadsorption

Coombs, R.R.A.; Gurner, B.W.; Oldham, G.; Barnes, M.J.;

Kieffer, M 377

Histamine in Nasal Secretions and Serum May Be Elevated

during Viral Respiratory Tract Infections

Smith, T.F.; Remigio, L.K 380

Effects of Levamisole and Z > -Penicillamine on Leucocyte Mi

gration into Sponge Exudates in Rats

West, G.B 384

Bordeîella pertussis-lnåuceà Impairment of Relaxation of Rat

Trachea to Isoprenaline and Histamine and Its Reversal

with Hydrocortisone

Norris, A.A.; Eyre, P 387

Book Reviews $\quad 390$

Announcements 391

Author Index 392

S. Karger $\cdot$ Medical and Scientific Publishers $\cdot$ Basel $\cdot$ München $\cdot$ Paris $\cdot$ London $\cdot$ New York Tokyo $\cdot$ Sydney

Drug Dosage 
The authors and the publisher have exerted every effort to ensure that drug selection and dosage set forth in this text are in accord with current recommendations and practice at the time of publication. However, in view of ongoing research, changes in government regulations, and the constant flow of information relating to drug therapy and drug reactions, the reader is urged to check the package insert for each drug for any change in indications and dosage and for added warnings and precautions. This is particularly important when the recommended agent is a new and/or infrequently employed drug.

All rights reserved.

No part of this publication may be translated into other languages, reproduced or utilized in any form or by any means, electronic or mechanical, including photocopying, recording, microcopying, or by any information storage and retrieval system, without permission in writing from the publisher.

S. Karger AG, P.O. Box, CH-4009 Basel (Switzerland)

Printed in Switzerland by Buchdruckerei Basler-Zeitung AG, Basel 